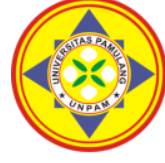

\title{
PENGARUH KUALITAS PELAYANAN DAN PERSEPSI HARGA TERHADAP PENINGKATAN PENJUALAN PADA PT. BFI FINANCE INDONESIA, TBK CABANG BINTARO
}

\author{
${ }^{1 *}$ Suhandi, ${ }^{2}$ Ade Yusuf, ${ }^{3}$ Yuyus Kadarusman \\ Universitas Pamulang, Tangerang Selatan, Banten, Indonesia \\ *dosen02501@unpam.ac.id
}

\begin{abstract}
Abstrak
Penelitian ini bertujuan untuk mengetahui pengaruh kualitas pelayanan dan persepsi harga terhadap peningkatan penjualan pada PT. BFI Finance Indonesia, Tbk Cabang Bintaro. Metode yang digunakan adalah explanatory research dengan teknik analisis menggunakan analisis statistik dengan pengujian regresi, korelasi, determinasi dan uji hipotesis. Hasil penelitian ini kualitas pelayanan berpengaruh signifikan terhadap peningkatan penjualan sebesar 40,7\%, uji hipotesis diperoleh $t$ hitung $>\mathrm{t}$ tabel atau $(7,867>1,987)$. Persepsi harga berpengaruh signifikan terhadap peningkatan penjualan sebesar $49,7 \%$, uji hipotesis diperoleh $t$ hitung $>\mathrm{t}$ tabel atau $(9,343>1,987)$. Kualitas pelayanan dan persepsi harga secara simultan berpengaruh signifikan terhadap peningkatan penjualan dengan persamaan regresi $Y=10,160+0,270 X 1+0,487 X 2$ dan kontribusi pengaruh sebesar $55,0 \%$, uji hipotesis diperoleh F hitung $>\mathrm{F}$ tabel atau $(54,327>2,710)$.

Kata Kunci: Kualitas Pelayanan, Persepsi Harga, Peningkatan Penjualan

\section{Abstract}

This study aims to determine the effect of service quality and price perception on increasing sales at PT. BFI Finance Indonesia, Tbk Bintaro Branch. The method used is explanatory research with analytical techniques using statistical analysis with regression, correlation, determination and hypothesis testing. The results of this study that service quality has a significant effect on increasing sales by $40.7 \%$, hypothesis testing is obtained $t$ count $>t$ table or $(7,867>1,987)$. Price perception has a significant effect on increasing sales by $49.7 \%$, hypothesis testing is obtained $t$ count $>t$ table or $(9.343>1.987)$. Service quality and price perception simultaneously have a significant effect on increasing sales with the regression equation $Y=10.160+0.270 X 1+0.487 X 2$ and the influence contribution is 55.0\%, hypothesis testing is obtained F count $>$ F table or $(54.327>2.710)$.

Keywords: Service Quality, Price Perception, Sales Increase.
\end{abstract}

\section{PENDAHULUAN}

Dalam menyelenggarakan dan menjalankan bisnis dalam sebuah organisasi, terlebih pada era kompetitif ini banyak sekali perusahaan yang menawarkan berbagai jenis pilihan produk maupun jasa. Setiap perusahaan saat ini di tuntut untuk menghasilkan produk yang bermutu dan berkualitas yang sesuai dengan harapan konsumen.

Sesungguhnya yang dibeli konsumen saat ini bukan hanya produk semata-mata dalam wujud fisiknya saja, melainkan manfaat pemenuhan kebutuhan dan keinginan konsumen. Menurut Bashu Swastha (2014:52) produk tidak hanya meliputi atribut fisik saja, tetapi juga mencangkup sifat-sifat non fisik, seperti harga, merk atau nama penjual, warna, pelayanan, citra dan sebagainya. Dalam berbagai hal dapat mempengaruhi keputusan konsumen dalam menentukan pilihan untuk membeli atau tidaknya suatu produk, misalnya: produk yang ditawarkan belum dibutuhkan, kualitas produk belum sesuai dengan harapan, ketersedian barang yang sulit didapat, pelayanan yang diberikan, harga yang kurang kompetitif dan lain sebagainya.

Menurut Philip Kotler dan Kevin Lan Keller yang dikutip dari buku manajemen 
pemasaran (2014:177). mengatakan bahwa kepuasan konsumen adalah perasaan senang atau kecewa seseorang yang muncul setelah membandingkan kinerja (hasil) produk yang difikirkan terdap kinerja yang diharapkan, hal tersebut dapat menimbulkan rasa puas dan tidaknya seorang konsumen dalam mengunakan barang dan jasa. Konsumen akan merasa puas apabila barang dan jasa yang ditawarkan sesuai dengan harapan, sebaliknya konsumen tidak akan merasa puas bila barang atau jasa yang digunakan tidak sesuai harapan.

Saat ini semakin banyaknya perusahaan yang menawarkan produk atau jasa yang sejenis di pasaran, hal tersebut membuat perusahaan saling berkompetisi untuk merebut hati para konsumen, dengan harapan konsumen mau menggunakan produk maupun jasa yang di tawarkan, dan dapat menjadi konsumen yang loyal terhadap perusahaan tersebut.

Dengan adanya kualitas pelayanan yang baik didalam perusahaan, akan menciptakan kepuasan bagi para konsumennya. Seperti menurut Tjiptono (2014:54) dalam Karundeng (2013:640) "kualitas pelayanan dapat diartikan sebagai upaya pemenuhan kebutuhan dan keinginan konsumen serta ketepatan dalam penyampaiannya dalam mengimbangi harapan konsumen". Setelah konsumen merasa puas atas produk atau jasa yang diterimanya, konsumen akan membandingkan pelayanan yang diberikan dengan tempat lain. Apabila konsumen benar-benar merasa puas, mereka akan kembali untuk membeli produk atau mempergunakan jasa, dan bahkan akan merekomendasikan kepada orang lain untuk membeli ditempat yang sama.

Selain itu ada faktor yang sangat mempengaruhi keputusan konsumen dalam memilih produk barang atau jasa. Harga adalah salah satu faktor penting dalam sebuah bisnis, karena banyak sekali perusahaan atau pelaku bisnis yang mengalami kegagalan dalam usahanya hanya dikarenakan salah dalam menentukan harga suatu barang atau jasa yang mereka produksi, yang mengakibatkan kalah dalam persaingan bisnis dengan para pesaing langsung. Baik harga yang terlalu tinggi yang mengakibatkan konsumen beralih ke tempat lain atau harga yang terlalu rendah, sehingga perusahaan mengalami kerugian, karena biaya yang dikeluarkan tidak sebanding dengan keuntungan yang didapat.

Menurut Philip kotler (2014:132): Harga adalah jumlah uang yang harus dibayar pelanggan untuk produk itu. Menurut Kotler dan Armstrong (2014:151): Sejumlah uang yang dibebankan atas suatu barang atau jasa atau jumlah dari nilai uang yang di tukar konsumen atas manfaat manfaat karena memiliki atau menggunakan produk atau jasa tersebut.

BFI adalah salah satu perusahaan yang bergerak dibidang jasa keuangan atau pembiayaan, dan saat ini banyak sekali perusahaan yang sejenis dengan BFI. Oleh karena itu perusahaan harus berfikir keras dalam menyikapi pesaing-pesaing yang ada saat ini, karena saat ini pesaing semakin berkembang pesat, baik dari sisi pelayanan, harga, dan sebagainya. Untuk itu perusahaan harus berlomba lomba untuk menarik minat konsumen dengan berbagai macam cara, mulai dari meningkatkan kualitas produk, promosi, pelayanan, harga dan lain sebagainya, karena hal tersebut mempengaruhi naik turunnya penjual pada suatu perusahaan. Oleh karena itu perusahaan di tuntut jeli dalam melihat kelemahan, kelebihan dari pesaing, dan peluang yang bisa didapat sehingga dapat mengantisipasi dan dapat segera mengambil keputusan untuk langkah selanjutnya dalam rangka mempertahankan kelangsungan perusahaan. Dan berikut data penjualan PT. BFI Finance, Tbk: 
Table 1. Data Penjualan PT. BFI Finance Tbk.Cabang Bintaro Periode Tahun 2014 - 2018

\begin{tabular}{|c|c|c|c|c|c|}
\hline Tahun & Target & Penjualan & Selisih & Persentasi (\%) & Keterangan \\
\hline 2014 & 1570 & 1352 & 218 & $86 \%$ & Baik \\
\hline 2015 & 1575 & 1110 & 465 & $70 \%$ & Buruk \\
\hline 2016 & 1570 & 1227 & 343 & $78 \%$ & Cukup \\
\hline 2017 & 1573 & 1216 & 357 & $77 \%$ & Cukup \\
\hline 2018 & 1550 & 1129 & 421 & $73 \%$ & Cukup \\
\hline Total & 7838 & 6034 & 1804 & $77 \%$ & Cukup \\
\hline Rata - Rata & 1567,6 & 1206,7 & 360,8 & $77 \%$ & Cukup \\
\hline
\end{tabular}

Keterangan : $<50 \%-70 \%$ ( buruk) $71 \%-85 \%$ ( cukup ) $86 \%-100 \%$ (baik ) $>100 \%$ ( sangan baik)

Dari data tabel di atas dapat dilihat bahwa PT.BFI Finance Cabang Bintaro selama lima tahun ke belakang tidak pernah mencapai angka 100\%. Dan dapat di lihat terjadi fluktuatif penjualan selama lima tahun kebelakang. Apalagi pada tahun 2015 dan 2018 terjadi penurunan yang sangat signifikan dari tahun - tahun sebelumnya, dan secara rata - rata hanya mencapai dan itu masuk dengan katagori "cukup". Hal tersebut menjadi sebuah perhatian dari pihak perusahaan apa yang menyebabkan terjadi naik turunnya penjualan, apakah disebabkan oleh faktor internal atau external. Dan berikut data perbandingan nominal pencairan, besarnya angsuran dari kompetitor di bandingkan PT. BFI Finance Tbk. 1.206,8 atau secara prosentasi di angka 77\%

Tabel 2. Tabel Harga PT. BFI Finance, Tbk.Cabang Bintaro Periode Tahun $2014-2018$

\begin{tabular}{|c|c|c|c|c|c|c|c|}
\hline \multirow{2}{*}{ Tahun } & \multirow{2}{*}{$\begin{array}{l}\text { Nominal } \\
\text { Pinjaman }\end{array}$} & \multicolumn{3}{|c|}{ Angsuran Selama 12 Bulan } & \multicolumn{3}{|c|}{ Nilai Estimasi Pinjaman (\%) } \\
\hline & & BFI & WOM & FIF & BFI & WOM & FIF \\
\hline 2014 & \multirow{5}{*}{$5,000,000$} & 605.500 & 593.000 & 587.000 & $70 \%$ & $85 \%$ & $75 \%$ \\
\hline 2015 & & 615.500 & 603.500 & 598.500 & $65 \%$ & $80 \%$ & $75 \%$ \\
\hline 2016 & & 636.000 & 617.500 & 610.500 & $73 \%$ & $75 \%$ & $75 \%$ \\
\hline 2017 & & 643.000 & 629.500 & 625.500 & $65 \%$ & $80 \%$ & $85 \%$ \\
\hline 2018 & & 644.500 & 638.500 & 633.500 & $60 \%$ & $85 \%$ & $80 \%$ \\
\hline
\end{tabular}

Sumber: PT. BFI Finance, Tbk. Cabang Bintaro 2018

Dari data tabel diatas dapat dilihat ada kenaikan harga yang cukup signifikan dari tahun ke tahun, dan juga perbandingan nominal angsuran dari kompetitor yang cukup jauh lebih tinggi di bandingkan dua kompetitor lain, dan juga terdapat nilai estimasi pinjaman yang lebih rendah dari kompetitor lain. Hal tersebut bisa jadi dapat mempengaruhi minat atau tingkat keputusan konsumen dalam memutuskan untuk mempergunakan barang atau jasa yang perusahaan tersebut tawarkan. Dan juga dapat berdampak pada naik turunnya penjualan pada perusahaan tersebut.

Hal ini menjadi perhatian serta tugas manajemen untuk dapat berupaya menarik

minat konsumen, sekaligus mempertahankan konsumennya. Hal ini dapat dilakukan dengan meningkatkan kualitas pelayanan dan Persepsi Harga yang diberikan karena ini merupakan salah satu faktor yang dapat menciptakan daya tarik atau minat pelanggan untuk mempergunakan produk atau jasa dari PT, BFI Finance Tbk. Sehinga dapat meningkatkan Penjualan pada PT. BFI Finance, Tbk. Berdasarkan uraian diatas, maka diajukan sebuah penelitian dengan judul " Pengaruh Kualitas Pelayanan Dan Persepsi Harga Terhadap Peningkatan Penjualan ".

Table 3. Jumlah Pelanggan PT.BFI Finance Indonesia Tbk. Cabang Bintaro Peride Tahun 2014 - 2018

\begin{tabular}{|c|c|c|c|c|c|}
\hline \multirow{2}{*}{ Tahun } & \multicolumn{3}{|c|}{ Jumlah Pelanggan PT. BFI Finance } & \multirow{2}{*}{ Keterangan } \\
\cline { 2 - 5 } & & & & & \\
\cline { 2 - 5 } & Target & Riil & Pertumbuhan & $(\%)$ & \\
\hline 2014 & 1.400 & 1.215 & - & - & - \\
\hline 2015 & 1.375 & 1.180 & -35 & $-3 \%$ & Turun \\
\hline 2016 & 1.325 & 1.205 & 25 & $2 \%$ & Naik \\
\hline
\end{tabular}




\begin{tabular}{|c|l|l|l|l|l|}
\hline 2017 & 1.350 & 1.175 & -30 & $-2 \%$ & Turun \\
\hline 2018 & 1.300 & 1.103 & -75 & $-6 \%$ & Turun \\
\hline Rata - Rata & 1.350 & 1.176 & -28 & $-2 \%$ & Turun \\
\hline
\end{tabular}

Sumber PT. BFI Finance, Tbk. Cabang Bintaro

Dari data tabel diatas dapat dilihat dari perkembangan jumlah pelanggan pada PT BFI Finance mengalami fluktuatif yang sangat jelas, hampir keseluruhan mengalami penurunan jumlah pelanggan dari tahun ke tahun. Hanya tahun 2016 yang mengalami peningkatan jumlah pelanggan dari tahun sebelumnya sebanyak 25 pelanggan, atau meningakat $2 \%$ dari tahun sebelumnya. Sedangkan tahun berikutnya terus mengalami penurunan, terlebih tahun 2018 penurunan hingga 72 pelanngan atau turun sebanyak $6 \%$ dari tahun sebelumnya.

Berdasarkan latar belakang di atas, maka penulis tertarik melakukan penelitian dengan judul "Pengaruh Kualitas Pelayanan Dan Persepsi Harga Terhadap Peningkatan Penjualan Pada PT. BFI Finance Indonesia, Tbk, Cabang Bintaro".

\section{TINJAUAN PUSTAKA}

\section{Kualitas Pelayanan}

Yang dimaksud kualitas produk dalam penelitian ini adalah Menurut Tjiptono (2012:98) “Kualitas pelayanan merupakan tingkat keunggulan yang diharapkan dan pengendalian atas tingkat keunggulan tersebut untuk memenuhi keinginan pelanggan". Adapun indikator yang dapat digunakan meliputi: Bukti fisik (Tangible), Empati (Empathy), Daya tanggap (Responsiveness), Kehandalan (Reliability), Jaminan (Assurance)

\section{Persepsi harga}

Yang dimaksud kualitas pelayanan dalam penelitian ini adalah menurut Rangkuti (2019:127). Persepsi mengenai harga diukur berdasarkan persepsi pelanggan yaitu dengan cara menanyakan kepada pelanggan variabel-variabel apa saat yang paling menurut mereka paling penting dalam memilih sebuah produk dan biaya relatif yang harus konsumen keluarkan untuk memperoleh produk atau jasa yang ia inginkan". Adapun Menurut Kotler (2014:278) adapun indikator yang ada dalam persepsi harga yaitu: Keterjangkauan harga, Kesesuaian harga dengan kualitas produk dan layanan, Daya saing harga, Harga yang diberikan kompetitif.

\section{Peningkatan Penjualan}

Dalam penelitian ini yang dijadikan variabel dependen adalah Peningkatan Penjualan Menurut Rangkuti (2013:207) yang dimaksud dengan "Peningkatan penjualan dalam penelitian ini yaitu pencapaian yang dinyatakan secara kuantitatif dari segi fisik atau volume atau unit dari suatu produk". Menurut Philip Kotler yang dikutip Swasta dan Irawan (2014:423) menyimpulkan bahwa ada beberpa indikator dari volume penjualan adalah sebagai berikut: Mencapai volume penjualan, Mendapatkan laba, Menunjang pertumbuhan perusahaan.

\section{METODE}

Populasi dalam penelitian ini berjumlah 92 responden PT. BFI Finance Indonesia, Tbk Cabang Bintaro. Sampel dalam penelitian ini berjumlah 92 responden. Jenis penelitian yang dipakai adalah asosiatif, dimana tujuannya adalah untuk mengetahui pengaruh antara variabel bebas terhadap variabel terikat baik parsial maupun simultan Dalam menganalisis data digunakan uji instrumen, uji asumsi klasik, regresi, koefisien determinasi dan uji hipotesis.

\section{HASIL DAN PEMBAHASAN}

\section{Analisis Deskriptif}

Pada pengujian ini digunakan untuk mengetahui skor minimum dan maksimum, mean score dan standar deviasi dari masing-masing variabel. Adapun hasilnya sebagai berikut: 
Tabel 4. Hasil Analisis Descriptive Statistics

Descriptive Statistics

\begin{tabular}{lr|r|r|r|r} 
& N & Minimum & Maximum & Mean & Std. Deviation \\
\hline Kualitas Pelayanan (X1) & 92 & 31 & 48 & 37.76 & 3.985 \\
\hline Persepsi Harga (X2) & 92 & 31 & 46 & 37.78 & 3.640 \\
\hline $\begin{array}{l}\text { Peningkatan Penjualan } \\
\text { Y) }\end{array}$ & 92 & 32 & 46 & 38.78 & 3.526 \\
\hline Valid N (listwise) & 92 & & & & \\
\hline
\end{tabular}

Kualitas pelayanan diperoleh varians minimum sebesar 31 dan varians maximum 48 dengan mean score sebesar 37,76 dengan standar deviasi 3,985.

Persepsi harga diperoleh varians minimum sebesar 31 dan varians maximum 46 dengan mean score sebesar 37,78 dengan standar deviasi 3,640.

Peningkatan penjualan diperoleh varians minimum sebesar 32 dan varians maximum 46 dengan mean score sebesar 38,78 dengan standar deviasi 3,526..

\section{Analisis Verifikatif.}

Pada analisis ini dimaksudkan untuk mengetahui pengaruh variabel independen terhadap variabel dependen. Adapun hasil pengujian sebagai berikut:

\section{a. Analisis Regresi Linier Berganda}

Uji regresi ini dimaksudkan untuk mengetahui perubahan variabel dependen jika variabel independen mengalami perubahan. Adapun hasil pengujiannya sebagai berikut:

Tabel 5. Hasil Pengujian Regresi Linier Berganda

\section{Coefficients ${ }^{a}$}

Unstandardized Coefficients

\begin{tabular}{ll|r|r|r|r|r}
\multicolumn{1}{l}{ Model } & \multicolumn{1}{c|}{$\begin{array}{c}\text { Std. } \\
\text { B }\end{array}$} & \multicolumn{1}{c}{ Error } & Beta & \multicolumn{1}{c}{$\mathrm{t}$} & \multicolumn{1}{c}{ Sig. } \\
\hline \multirow{2}{*}{1} & (Constant) & 10.160 & 2.757 & & 3.685 & .000 \\
\cline { 2 - 8 } & Kualitas Pelayanan (X1) & .270 & .084 & .306 & 3.221 & .002 \\
\cline { 2 - 8 } & Persepsi Harga (X2) & .487 & .092 & .503 & 5.302 & .000 \\
\hline
\end{tabular}

a. Dependent Variable: Peningkatan Penjualan (Y)

Berdasarkan hasil pengujian pada tabel di atas, diperoleh persamaan regresi $\mathrm{Y}=10,160+$ 0,270X1 + 0,487X2. Dari persamaan tersebut dijelaskan sebagai berikut:

1) Konstanta sebesar 10,160 diartikan jika kualitas pelayanan dan persepsi harga tidak ada, maka telah terdapat nilai peningkatan penjualan sebesar 10,160 point.

2) Koefisien regresi kualitas pelayanan sebesar 0,270 , angka ini positif artinya setiap ada peningkatan kualitas pelayanan sebesar 0,270 maka peningkatan penjualan juga akan mengalami peningkatan sebesar 0,270 point.
3) Koefisien regresi persepsi harga sebesar 0,487, angka ini positif artinya setiap ada peningkatan persepsi harga sebesar 0,487 maka peningkatan penjualan juga akan mengalami peningkatan sebesar 0,487 point.

\section{b. Analisis Koefisien Korelasi}

Analisis koefisien korelasi dimaksudkan untuk mengetahui tingkt kekuatan hubungan dari variabel independen terhadap variabel dependen baik secara parsial maupun simultan. Adapun hasil pengujian sebagai berikut: 
Tabel 6. Hasil Pengujian Koefisien Korelasi Kualitas pelayanan Terhadap Peningkatan penjualan.

\begin{tabular}{|c|c|c|c|}
\hline \multicolumn{4}{|c|}{ Correlations ${ }^{b}$} \\
\hline & & $\begin{array}{c}\text { Kualitas } \\
\text { Pelayanan (X1) }\end{array}$ & $\begin{array}{l}\text { Peningkatan } \\
\text { Penjualan }(Y)\end{array}$ \\
\hline \multirow[t]{2}{*}{ Kualitas Pelayanan (X1) } & $\begin{array}{l}\text { Pearson } \\
\text { Correlation }\end{array}$ & 1 & $.638^{* *}$ \\
\hline & Sig. (2-tailed) & & .000 \\
\hline \multirow[t]{2}{*}{$\begin{array}{l}\text { Peningkatan Penjualan } \\
\text { (Y) }\end{array}$} & $\begin{array}{l}\text { Pearson } \\
\text { Correlation }\end{array}$ & $.638^{* *}$ & 1 \\
\hline & Sig. (2-tailed) & .000 & \\
\hline
\end{tabular}

**. Correlation is significant at the 0.01 level (2-tailed).

b. Listwise $\mathrm{N}=92$

Berdasarkan hasil pengujian diperoleh nilai korelasi sebesar 0,638 hubungan yang kuat terhadap artinya kualitas pelayanan memiliki peningkatan penjualan.

Tabel 7. Hasil Pengujian Koefisien Korelasi Persepsi harga Terhadap Peningkatan penjualan. Correlations $^{b}$

\begin{tabular}{llr|r} 
& & \multicolumn{1}{c|}{$\begin{array}{c}\text { Persepsi } \\
\text { Harga (X2) }\end{array}$} & \multicolumn{1}{c}{$\begin{array}{c}\text { Peningkatan } \\
\text { Penjualan (Y) }\end{array}$} \\
\hline Persepsi Harga (X2) & Pearson Correlation & 1 & $.705^{\star *}$ \\
\cline { 2 - 4 } & Sig. (2-tailed) & & .000 \\
\hline $\begin{array}{l}\text { Peningkatan Penjualan } \\
\text { (Y) }\end{array}$ & Pearson Correlation & $.705^{* *}$ & 1 \\
\cline { 2 - 4 } & Sig. (2-tailed) & .000 & \\
\hline
\end{tabular}

**. Correlation is significant at the 0.01 level (2-tailed).

b. Listwise $\mathrm{N}=92$

Berdasarkan hasil pengujian diperoleh nilai korelasi sebesar 0,705 artinya persepsi harga memiliki

hubungan yang kuat terhadap peningkatan penjualan.

Tabel 8. Hasil Pengujian Koefisien Korelasi Kualitas pelayanan dan Persepsi harga secara simultan Terhadap Peningkatan penjualan.

Model Summary

\begin{tabular}{l|c|c|cr} 
& & \multicolumn{2}{|c|}{$\begin{array}{c}\text { Modjusted R } \\
\text { Model }\end{array}$} & \multicolumn{2}{c}{$\begin{array}{c}\text { Std. Error of the } \\
\text { R }\end{array}$} & R Square & Square & \multicolumn{2}{c}{ Estimate } \\
\hline 1 & $.741^{\mathrm{a}}$ & .550 & .540 & 2.393 \\
\hline a. Predictors: (Constant), Persepsi Harga (X2), Kualitas Pelayanan (X1)
\end{tabular}

Berdasarkan hasil pengujian diperoleh nilai korelasi sebesar 0,741 artinya kualitas pelayanan dan persepsi harga secara simultan memiliki hubungan yang kuat terhadap peningkatan penjualan.
Analisis koefisien determinasi dimaksudkan untuk mengetahui besarnya persentase pengaruh dari variabel independen terhadap variabel dependen baik secara parsial maupun simultan. Adapun hasil pengujian sebagai berikut:

\section{c. Analisis Koefisien Determinasi}

Tabel 9. Hasil Pengujian Koefisien Determinasi Kualitas pelayanan Terhadap Peningkatan penjualan.

\section{Model Summary}

\begin{tabular}{l|r|r|r|r} 
& & \multicolumn{2}{|c|}{} & \multicolumn{2}{c}{ Adjusted R } & \multicolumn{2}{c}{$\begin{array}{c}\text { Std. Error of the } \\
\text { Model }\end{array}$} & R & R Square & Square & Estimate \\
\hline 1 & $.638^{\mathrm{a}}$ & .407 & .401 & 2.730 \\
\hline
\end{tabular}


a. Predictors: (Constant), Kualitas Pelayanan (X1)

Berdasarkan hasil pengujian memiliki kontribusi pengaruh sebesar diperoleh nilai determinasi sebesar 0,407 artinya kualitas pelayanan $40,7 \%$ terhadap peningkatan penjualan.

Tabel 10. Hasil Pengujian Koefisien Determinasi Persepsi harga Terhadap Peningkatan penjualan.

Model Summary

\begin{tabular}{|c|c|c|c|c|}
\hline Model & $\mathrm{R}$ & R Square & $\begin{array}{l}\text { Adjusted R } \\
\text { Square }\end{array}$ & $\begin{array}{l}\text { Std. Error of the } \\
\text { Estimate }\end{array}$ \\
\hline 1 & $.705^{a}$ & .497 & .492 & 2.51 \\
\hline
\end{tabular}

a. Predictors: (Constant), Persepsi Harga (X2)

Berdasarkan hasil pengujian diperoleh nilai determinasi sebesar kontribusi pengaruh sebesar 49,7\% 0,497 artinya persepsi harga memiliki terhadap peningkatan penjualan.

Tabel 11. Hasil Pengujian Koefisien Determinasi Kualitas pelayanan dan Persepsi harga Terhadap Peningkatan penjualan.

\section{Model Summary}

\begin{tabular}{lr|r|r|rr} 
Model & R & R Square & $\begin{array}{c}\text { Adjusted R } \\
\text { Square }\end{array}$ & \multicolumn{2}{|c}{$\begin{array}{c}\text { Std. Error of the } \\
\text { Estimate }\end{array}$} \\
\hline 1 & $.741^{\mathrm{a}}$ & .550 & .540 & 2.393 \\
\hline
\end{tabular}

a. Predictors: (Constant), Persepsi Harga (X2), Kualitas Pelayanan (X1)

Berdasarkan hasil pengujian diperoleh nilai determinasi sebesar 0,550 artinya kualitas pelayanan dan persepsi harga secara simultan memiliki kontribusi pengaruh sebesar $55,0 \%$ terhadap peningkatan penjualan, sedangkan sisanya sebesar $45,0 \%$ dipengaruhi faktor lain.

\section{d. Uji Hipotesis}

Uji hipotesis Parsial (Uji t)

Pengujian hipotesis dengan uji $t$ digunakan untuk mengetahui hipotesis parsial mana yang diterima.

Hipotesis pertama: Terdapat pengaruh yang signifikan antara kualitas pelayanan terhadap peningkatan penjualan.

Tabel 12. Hasil Uji Hipotesis Kualitas pelayanan Terhadap Peningkatan penjualan.

\section{Coefficients ${ }^{\mathrm{a}}$}

\begin{tabular}{|c|c|c|c|c|c|}
\hline \multirow[b]{2}{*}{ Model } & \multicolumn{2}{|c|}{$\begin{array}{l}\text { Unstandardized } \\
\text { Coefficients }\end{array}$} & \multirow{2}{*}{$\begin{array}{c}\text { Standardize } \\
\mathrm{d} \\
\text { Coefficients } \\
\text { Beta } \\
\end{array}$} & \multirow[b]{2}{*}{$\mathrm{t}$} & \multirow[b]{2}{*}{ Sig. } \\
\hline & $\mathrm{B}$ & Std. Error & & & \\
\hline (Constant) & 17.449 & 2.727 & & 6.400 & .000 \\
\hline Kualitas Pelayanan (X1) & .565 & .072 & .638 & 7.867 & .000 \\
\hline
\end{tabular}

a. Dependent Variable: Peningkatan Penjualan (Y)

Berdasarkan hasil pengujian pada tabel di atas, diperoleh nilai $\mathrm{t}$ hitung $>\mathrm{t}$ tabel atau $(7,867>1,987)$, dengan demikian hipotesis pertama Tabel 13. Hasil Uji Hipotesis Persepsi harga Terhadap Peningkatan penjualan.

\section{Coefficients ${ }^{a}$}

Unstandardized

Coefficients

\begin{tabular}{lc|r|c|c|c} 
Model & B & Std. Error & Beta & t & Sig. \\
\hline $1 \quad$ (Constant $)$ & 12.971 & 2.748 & & 4.719 & .000 \\
\hline
\end{tabular}

yang diajukan bahwa terdapat pengaruh yang signifikan atara kualitas pelayanan terhadap peningkatan penjualan diterima.

\begin{tabular}{|c|c|c|}
$\begin{array}{c}\text { Standardized } \\
\text { Coefficients } \\
\text { Beta }\end{array}$ & $\mathrm{t}$ & Sig. \\
\hline & 4.719 & .000 \\
\hline
\end{tabular}




\begin{tabular}{ll|l|l|l|l}
\hline $\begin{array}{l}\text { Persepsi Harga } \\
(\mathrm{X} 2)\end{array}$ & .683 & .072 & .705 & 9.434 & .000 \\
\hline
\end{tabular}

a. Dependent Variable: Peningkatan Penjualan (Y)

Berdasarkan hasil pengujian pada tabel di atas, diperoleh nilai $\mathrm{t}$ hitung $>\mathrm{t}$ tabel atau $(9,343>1,987)$, dengan demikian hipotesis kedua yang diajukan bahwa terdapat pengaruh yang signifikan atara persepsi harga terhadap peningkatan penjualan diterima.

\section{Uji Hipotesis Simultan (Uji F)}

Pengujian hipotesis dengan uji $\mathrm{F}$ digunakan untuk mengetahui hipotesis simultan yang mana yang diterima.

Hipotesis ketiga Terdapat pengaruh yang signifikan antara kualitas pelayanan dan persepsi harga terhadap peningkatan penjualan.

Tabel 14. Hasil Uji Hipotesis Kualitas pelayanan dan Persepsi harga Terhadap Peningkatan penjualan.

\begin{tabular}{|c|c|c|c|c|c|c|}
\hline \multicolumn{7}{|c|}{ ANOVA $^{a}$} \\
\hline \multicolumn{2}{|c|}{ Model } & Sum of Squares & $\mathrm{df}$ & $\begin{array}{l}\text { Mean } \\
\text { Square }\end{array}$ & $\mathrm{F}$ & Sig. \\
\hline \multirow[t]{3}{*}{1} & Regression & 622.092 & 2 & 311.046 & 54.327 & $.000^{\mathrm{b}}$ \\
\hline & Residual & 509.560 & 89 & 5.725 & & \\
\hline & Total & 1131.652 & 91 & & & \\
\hline
\end{tabular}

a. Dependent Variable: Peningkatan Penjualan (Y)

b. Predictors: (Constant), Persepsi Harga (X2), Kualitas Pelayanan (X1)

Berdasarkan hasil pengujian pada tabel di atas, diperoleh nilai $\mathrm{F}$ hitung > F tabel atau $(54,327>2,710)$, dengan demikian hipotesis ketiga yang diajukan bahwa terdapat pengaruh yang signifikan atara kualitas pelayanan dan persepsi harga terhadap peningkatan penjualan diterima.

\section{PEMBAHASAN HASIL PENELITIAN}

\section{Pengaruh Kualitas pelayanan}

Terhadap Peningkatan penjualan

Kualitas pelayanan berpengaruh signifikan terhadap peningkatan penjualan dengan korelasi sebesar 0,638 atau memiliki hubungan yang kuat dengan kontribusi pengaruh sebesar $40,7 \%$. Pengujian hipotesis diperoleh nilai t hitung $>\mathrm{t}$ tabel atau $(7,867>1,987)$. Dengan demikian hipotesis pertama yang diajukan bahwa terdapat berpengaruh signifikan antara kualitas pelayanan terhadap peningkatan penjualan diterima.

\section{Pengaruh Persepsi harga Terhadap} Peningkatan penjualan

Persepsi harga berpengaruh signifikan terhadap peningkatan penjualan dengan korelasi sebesar 0,705 atau memiliki hubungan yang kuat dengan kontribusi pengaruh sebesar $49,7 \%$. Pengujian hipotesis diperoleh nilai thitung $>\mathrm{t}$ tabel atau $(9,343>1,987)$. Dengan demikian hipotesis kedua yang diajukan bahwa terdapat berpengaruh signifikan antara persepsi harga terhadap peningkatan penjualan diterima.

3. Pengaruh Kualitas pelayanan dan Persepsi harga Terhadap Peningkatan penjualan

Kualitas pelayanan dan persepsi harga berpengaruh signifikan terhadap peningkatan penjualan dengan diperoleh persamaan regresi $Y=10,160+$ 0,270X1 + 0,487X2, nilai korelasi sebesar 0,741 atau memiliki hubungan yang kuat dengan kontribusi pengaruh sebesar $55,0 \%$ sedangkan sisanya sebesar $45,0 \%$ dipengaruhi faktor lain. Pengujian 
hipotesis diperoleh nilai $\mathrm{F}$ hitung $>\mathrm{F}$ tabel atau $(54,327>2,710)$. Dengan demikian hipotesis ketiga yang diajukan bahwa terdapat berpengaruh signifikan antara kualitas pelayanan dan persepsi harga terhadap peningkatan penjualan diterima.

\section{PENUTUP}

\section{Kesimpulan}

1. Kualitas pelayanan berpengaruh signifikan terhadap peningkatan penjualan dengan kontribusi pengaruh sebesar 40,7\%. Uji hipotesis diperoleh nilai thitung $>t$ tabel atau $(7,867>1,987)$.

2. Persepsi harga berpengaruh signifikan terhadap peningkatan penjualan dengan kontribusi pengaruh sebesar $49,7 \%$. Uji hipotesis diperoleh nilai $\mathrm{t}$ hitung $>\mathrm{t}$ tabel atau $(9,343>1,987)$.

3. Kualitas pelayanan dan persepsi harga berpengaruh signifikan terhadap peningkatan penjualan dengan kontribusi pengaruh sebesar 55,0\% sedangkan sisanya sebesar $45,0 \%$ dipengaruhi faktor lain. Uji hipotesis diperoleh nilai $\mathrm{F}$ hitung $>\mathrm{F}$ tabel atau $(54,327>2,710)$.

\section{Saran}

1. Kualitas Pelayanan, indikator yang paling lemah adalah jaminan (Assurance) Untuk lebih baik lagi perusahaan harus memperhatikan terkait kemudahan dalam proses pengambilan BPKB sehingga pelanggan tidak merasa dipersulit, dan juga memberikan estimasi waktu kepada pelanggan yang lebih jelas dan komit dalam memastikan waktu untuk penyerahan BPKB tersebut, agar pelanggan tidak merasa di bohongi atau tidak diberikan kepastian atas janji perusahaan dan karyawan kepada pelanggan.

2. Persepsi Harga, indikator yang paling lemah adalah kesesuaian harga Untuk lebih baik lagi perusahaan harus lebih dapat memberikan estimasi yang sesuai dengan permintaan pelanggan, mengingat persaingan yang begitu ketat dilapangan terkait besarnya estimasi pinjaman pelanggan yang diberikan oleh kompetitor.

3. Peningkatan Penjualan, indikator yang paling lemah adalah mendapatkan laba tertentu. Untuk lebih baik lagi perusahaan harus meningkatkan lagi indikator yang cukup mempengaruhi pada peningkatan penjualan, bukan hanya sekedar harga dan kualitas pelayanan, namun dengan melakukan berbagai macam strategi pemasaran agar dapat meningkatkan penjualan, seperti promosi, direct saling, dan lain sebagainya.

4. Kontibusi pengaruh variabel bebas terhadap variabel terikat sebesar 55,0\%, nilai ini masih bisa ditingkatkan dengan secara selektif dapat memprioritaskan pesanan pelanggan yang harus dipenuhi dan kondisi masing-masing variabel bebas harus ditingkatkan secara signifikan. Oleh karenanya disarankan kepada penelitian berikutnya agar melakukan penelitian yang relevan dengan cara memperbaiki indikator yang masih tidak baik atau dengan menambah indikator pertanyaan dan jumlah responden penelitian sehingga akan dapat lebih diketahui variabel yang paling memberikan kontribusi positif bagi perusahaan.

\section{DAFTAR PUSTAKA}

Algifari, "Analisis Regresi", Yogyakarta, 2013.

Ardiansyah, G. (2019). Perbandingan Tingkat Produksi Dan Volume Penjualan Bawang Daun Organik Dan Anorganik Di Koperasi Mitra Sejahtera Cianjur. Agroscience (AGSCI), 9(2), 167-177.

Arikunto, Suharsimi, "Prosedur Penelitian Suatu Pendekatan Praktek", PT. Rineka Cipta, Jakarta, 2013.

Basu Swastha, Dharnesta dan Irawan, "Manajemen Pemasaran Modern", Liberty, Yogyakarta, 2014.

Dharmayuni, L., Sunarsi, D., Sembiring, E. S. K., Satata, S., Bahrudin, U., Erlangga, H., ... \& Salam, A. F. (2021). Effect of Distribution Cost and 
Promotion Cost on Tyre Industries Sales Performance. Annals of the Romanian Society for Cell Biology, 12672-12684.

Dwi Rompis, Wilem Tumbuan, Jacky Sumaurauw, ISSN:2303-1174. Vol.05 No.03 (2017). Pengaruh Pengaruh Bauran Pemasaran Terhadap Volume Penjualan Pada PT Tridjaya Mulia Sukses.

Erlangga, H. (2021). Effect Of Digital Marketing And Social Media On Purchase Intention Of Smes Food Products. Turkish Journal of Computer and Mathematics Education (TURCOMAT), 12(3), 3672-3678.

G.R. Terry, and Rue, Leslie W. Rue, "Dasardasar Manajemen", Bumi Aksara, Jakarta 2013.

Ghozali, Imam, 2014, "Aplikasi Analisis Multivariate dengan Program IBM SPSS 23"., Semarang, Badan Penerbit Universitas Diponogoro.

Haque, M. G., Nurjaya, N., Affandi, A., Erlangga, H., \& Sunarsi, D. (2021). Micro Financial Sharia Non-bank Strategic Analysis: a Study at BMT Beringharjo, Yogyakarta. Budapest International Research and Critics Institute (BIRCI-Journal): Humanities and Social Sciences, 4(2), 1677-1686.

Hasan, Ali, "Marketing". Media Utama., Yogyakarta, 2013

Hindarsah, I. (2021). The Influence of Service Quality, Emotional Marketing and Spiritual Marketing On Customer Satisfaction. Turkish Journal of Computer and Mathematics Education (TURCOMAT), 12(3), 3685-3689.

Keller dan Amstrong, "Prinsip-prinsip Pemasaran", Edisi Kedua Belas, Jilid Satu, Erlangga, Jakarta, 2014.

Kotler "Manajemen Pemasaran", Edisi Keempat belas, PT. Indeks, Jakarta, 2014.

Marbun, B.N, 2013, Kamus Manajemen, Pustaka Sinar Harapan, Jakarta

Yulistiana, I., Dewi, R. V., Mas' adi, M., Sunarsi, D., \& Erlangga, H. (2021). Did Brand Perceived Quality, Image Product And Place Convenience
Muhamad In'amul Chulaifii, Endang Setyowati, ISSN: 2579-7980. Vol.03 No.01 (2018). Pengaruh Kualitas Pelayanan, Persepsi Harga dan Kepercayaan Terhadap Konsumen Jasa Travel Umrah dan Haji PT. Sebaris Warna Berkah di Surabaya.

Nurjaya, N. P. M. (2019). Pengaruh Sumber Daya Inti, Sumber Daya Kritikal, Market Based Terhadap Nilai Pelanggan Dan Kepuasan Pelanggan Serta Implikasinya Pada Loyalitas Pelanggan Pada Umkm Produk Gula Aren (Doctoral dissertation, Universitas Pasundan).

Priyatno, Duwi, 2014, "SPSS Untuk Analisa Korelasi, Regresi, dan Multivariate", Penerbit Gava Media, Yogyakarta.

Rangkuti Freddy, 2013. "Strategi Promosi Yang Kreatif", edisi pertama, cetakan pertama, Penerbit : Gramedia Pustaka Utama, Jakarta.

Santoso, Singgih, 2014, "Statistik Parametik", Jakarta. PT Gramedia Pustaka Umum.

Setiawati, N. P. A., Sunarsi, D., Nurjaya, S., Manan, A., Nurhadi, A., Erlangga, H., ... \& Purwanto, A. (2021). Effect of Technology Acceptance Factors, Website Service Quality and Specific Holdup Cost on Customer Loyalty: A Study in Marketing Departement of Packaging Industry. Annals of the Romanian Society for Cell Biology, 12685-12697.

Sugiyono, "Metode Penelitian Kuantitatif Kualitatif dan $R \mathcal{E} D^{\prime \prime}$, Penerbit CV. Alfabeta, Bandung, 2016.

Sunyoto, Danang. 2014, "Strategi Pemasaran", Yogyakarta CAPS.

Tjiptono, Fandy dan Gregorius Chandra, "Serivce Quality and Satisfiation", Edisi tiga, Andi, Jakarta, 2014.

Y Kadarusman, D Sunarsi. (2020). Pengaruh Strategi Penetapan Harga Terhadap Peningkatan Jumlah Siswa Pada SMK PGRI Balaraja. JS (JURNAL SEKOLAH) 4 (3), 213-221.

Influence Customer Loyalty Through Unique Value Proposition?. Journal of Contemporary Issues in Business and Government, 27(1), 2854-2867. 